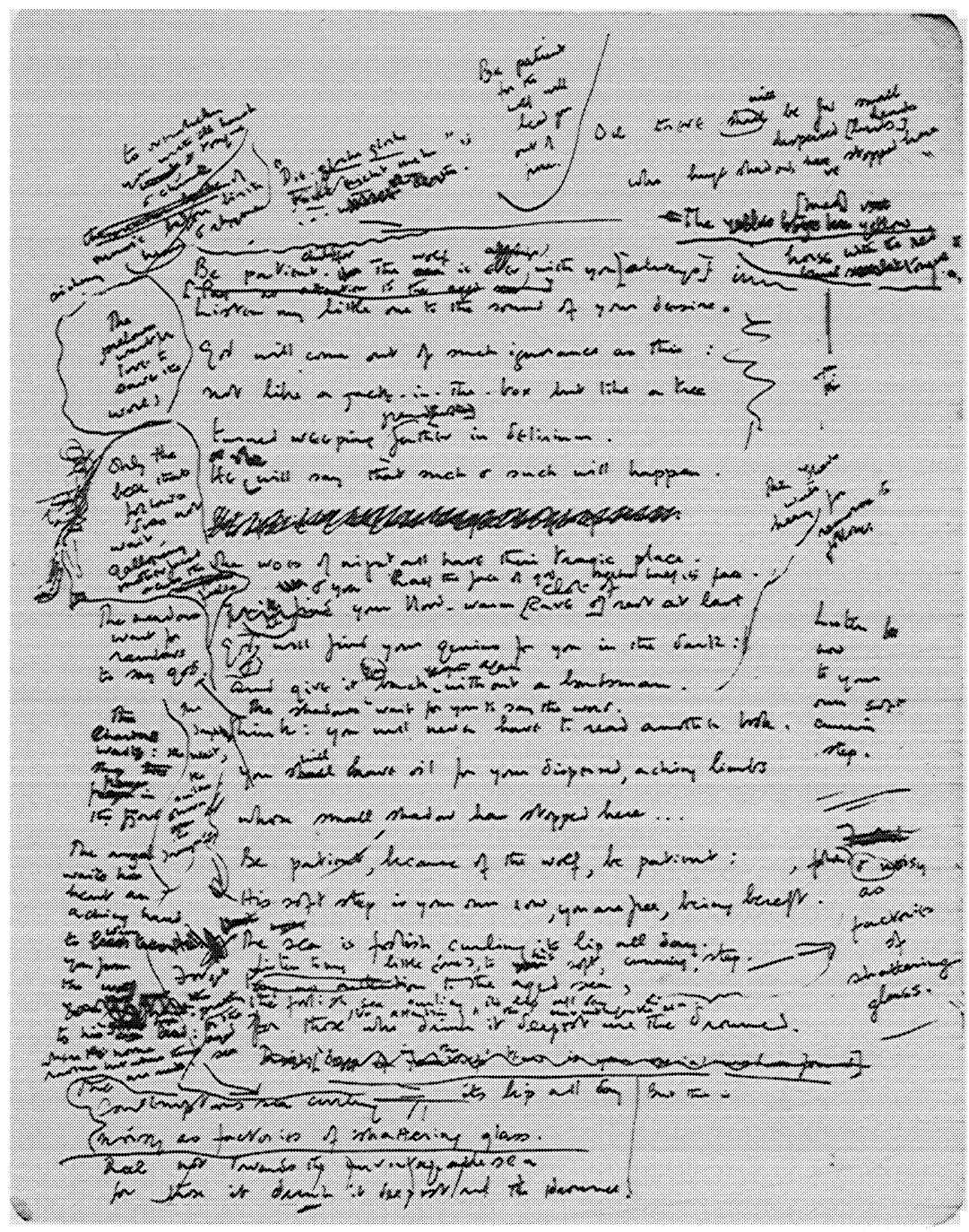

Malcolm Lowry, HM of 'Be Patient For the Wolf,' Malcolm Lowry Papers, University of British Columbia Library, Special Collections Division, Box 4, File 17. Reproduced by permission of the Estate of Malcolm Lowry and the University of British Columbia Library. 


\title{
Unearthing Malcolm Lowry's Two Unknown Volumes of Poetry
}

\author{
Kathleen Scherf
}

Although his literary fame and reputation rest exclusively on his fiction, Malcolm Lowry (I 909-I 957) considered himself to be primarily a poet. The sheer mass of poems he composed justifies our critical attention, as does the serious regard with which he approached the genre. In 1937, for example, a depressed and paranoid Lowry asked his Mexican friend Juan Fernando Marquez:

Have these guys [spies] nothing better to do than to watch a man who merely wants to write poetry? As if I had not enough troubles on my mind!

Almost a decade later, in January I946, when Lowry posted to Jonathan Cape his well-known and widely-quoted defence of the structure and style of Under the Volcano, he again highlighted the importance of poetry in his creative imagination:

... the author's equipment, such as it is, is subjective rather than objective, a better equipment, in short, for a certain kind of poet than a novelist.

Another decade later, in the last year of his life, Lowry wrote from England to Ralph Gustafson, who included two of Lowry's poems in the 1958 Penguin Book of Canadian Verse:

Sometimes I think I've never been able fully to understand the most elementary principles of scansion, stress, interior rhyme and the like with the result, by overcompensation, that my poems such as they are look as though they

Kathleen Scherf teaches in the Department of English at the University of New Brunswick, Fredericton, New Brunswick. She is the editor of Studies in Canadian Literature / Études en littérature canadienne. Her scholarly edition of The Collected Poetry of Malcolm Lowry will be published in r99 I by the University of British Columbia Press. 
had a kind of wooden monotonous classical frame.... All this is very sad and complicated to me because I think of practically nothing else but poetry... ${ }^{2}$

These letters, written at twenty-eight, thirty-seven, and forty-eight years of age, are representative expressions of Lowry's sustained concern for his poetic development and career. The number of poems he composed and the significant position poetry held in his consciousness argue strongly for giving more scholarly attention to Lowry's poetry.

Furthermore, the poetry complements the fiction in many ways thematically, topically, and especially biographically - so that it often serves as a convenient commentary on the prose, illuminating the mental and emotional processes that Lowry employed in adapting, translating, and transfiguring poetic impulses into language and strategies suitable for fiction. In all his writing, Lowry's compositional method combined his verse and prose. For example, he composed the poem 'Pines Write a Chinese Poem Upon the White-Gold Sun' on the holograph manuscript of the story 'The Present Estate of Pompeii,' one of the short stories collected in Hear Us O Lord from Heaven Thy Dwelling Place. Preceding the poem, at the top of the sheet, Lowry wrote:

Also, in II, when Downey reflects at the top of the Wilderness steps, while they are swimming, I write this in poetry, which it is: ... but I think, if a long story, its substance should be here.

The two-page poem follows, after which the prose continues. Though the poem does not survive in the published story, it was an integral part of the story's composition and development. The manuscripts for Dark as the Grave Wherein My Friend is Laid and 'Through the Panama' also contain poems. These poems are significant as evidence of how frequently for Lowry the conceptual process for his prose began in what he considered to be a poetic vision. This relationship also exists between the poetry volume The Lighthouse Invites the Storm and the novel Under the Volcano. According to Earle Birney:

... [Lowry] was too self-centered, too inexperienced about others, to be contented with prose fiction alone; when he felt most deeply he turned to verse, especially after he came under the influence of Conrad Aiken. Indeed some of the most powerful passages in Under the Volcano were first written as verse. By the time he came to Dollarton he had the habit of recording whatever day-to-day experiences most moved him in poetic form, seeing an eagle, finding a strange flower. And later he would re-work some of these poems into the prose of his Volcano and his later novels. ${ }^{3}$ 
Aside from those poems important because of contexts shared with the prose works, or because of their biographical relevance, there is in the canon a core of highly successful poems - works one might wish to anthologize as among the best or most representative of Lowry as poet. Lowry collected these poems into two volumes which remain unpublished: The Lighthouse Invites the Storm [poems I934-40] and the tentatively titled Wild Bleeding Hearts [poems 1940-47]. The Lighthouse is a unified work of linked poems which narrates the physical and emotional journey of Peter Gaunt, whose fortunes offer a curious intertext with those of Ibsen's Peer Gynt. With three exceptions, Lowry composed all of the poems in the second volume while living on the beach at Dollarton, British Columbia. This collection, especially the 'Poems from Vancouver' section, contains particularly good examples of Lowry's descriptive ability to capture the land and seascapes and to depict with poignant accuracy the squatter life on the beach. The best poems in this group place Lowry firmly in the tradition of Canadian nature poetry. 'Indian Arm,' for example, presents a vivid, natural picture of the beach on a late November afternoon:

Mill-wheel reflections of sun on water

And the spokes of light wheeling on the shacks,

Such freshness of wind in a spring quarter

Such radiance for November! While oil tracks

Make agate patterns, a tanker passes

- sudden sleeked lead boils on the beach, attacks

Boats under houses, the bowed band grasses,

Reflections are shivered, wild spokes unreel

The day booms a song of foaming basses.

... Softly renews the round of the mill-wheel

Sun reflections winding longer shadows

Turn pine bough into green chenille.

After the moonlight walks over windrows

Mill-wheel reflections of moonlight later

On water embroider waving windows.... ${ }^{4}$

What distinguishes 'Indian Arm' and other collected and uncollected poems, such as 'The Wild Cherry,' 'Port Moody,' 'A Picture,' and 'Pines Write a Chinese Poem Upon the White-Gold Sun,' is the poetic vision that infuses the land-sea descriptions, capturing in the process that sense of 
the wildness of the landscape that inspires the best Canadian nature poetry. In 'Pines Write,' for instance, Lowry describes the hardness and sharpness of the land:

Gigantic, the pines against the Chinese sun

Illumined and embodied by light, the pines are real

That were broken bottles guarding the hill. ${ }^{5}$

The lines echo similar sentiments in A.J.M. Smith's 'The Lonely Land' (first published in book form in I936), in which 'Cedar and jagged fir / uplift sharp barbs / against the gray / and cloud-piled sky'; but whereas Smith seems to be striving, in both his descriptive sparseness and the brevity of his lines, for a kind of imagistic effect, Lowry's perspective, with its longer line, is softened and more expansive; as a result it is more lyrical, more personal, and, in a word, more romantic - a quality that characterizes much of Lowry's poetry and accounts paradoxically for both its successes and its failures, as well as its fascination.

Lowry critics interested in his poetry, unless they have access to the manuscripts in the University of British Columbia (U.B.c.) Library, must rely on Earle Birney's I962 edition of Selected Poems of Malcolm Lowry, published in San Francisco by City Lights Books. That any of the poetic texts has been available is owing to the efforts of Earle Birney during the early i 960 s. Single-handedly, he placed over roo of the poems in journals and little magazines. Birney's intentions were clearly laudable; however, there are serious problems with Selected Poems. Beyond its incompleteness - the volume contains fewer than one-seventh of the total number of poems - the structure of the collection reflects Birney's, not Lowry's, vision of Lowry's first (and unpublished) volume of poetry, The Lighthouse Invites the Storm. Birney's selection encompasses poems which date from every one of Lowry's compositional periods, which span thirty years; yet, despite the fact that Lowry had finished with the Lighthouse seventeen years before he died, Birney insists on forcing all the Selected Poems material into the Lighthouse structure on the premise that Lowry all his life intended to revise this particular collection to include his poetic canon. No bibliographical or contextual evidence for Birney's hypothesis exists; on the contrary, it is clearly evident that Lowry thought of and treated Lighthouse as a discrete volume. Furthermore, Birney expands the original Lighthouse structure to include four non-authorial section headings while omitting two authorial ones. ${ }^{6}$

Far more serious, and not restricted to Selected Poems, but also apparent in journal publications during the I960s, is Birney's editorial policy of silently emending so much of the poetry. For example, the five-page 
authorial manuscript for 'Pacific is a feeble symbol of death' is I I 4 lines long, untitled, and undivided into stanzas. In Birney's Selected Poems, the poem runs fifty-one lines, is titled, and appears neatly split into regular stanzas (see photos). While it is true that Birney's revisions sometimes sharpen a particular poem, they also pose serious critical problems for readers familiar only with the texts as published in journals and Selected Poems, because critics who use these texts as the basis for their comments on Lowry's poems are not really commenting on Lowry's poems at all.

Most of Malcolm Lowry's poetic manuscripts are preserved in the Malcolm Lowry Papers in the Special Collections Division of the University of British Columbia Library. Lowryans who do have access to this extensive collection have at their disposal over sixty boxes of correspondence, manuscripts, typescripts, published works, photos, and memorabilia, as well as a full complement of critical works on Lowry. The manuscripts and typescripts for the 296 poems in the inventory are, with few exceptions, located in boxes four through seven, which contain individual files, alphabetically arranged, for each poem. Any given file contains all the U.B.C. manuscripts or typed drafts of a particular poem, except for some drafts - usually one which are included in the two unpublished authorial collections, filed separately: The Lighthouse Invites the Storm in box six, file fifty-one, and the I947 collection in box seven, file two.

The inventory arrangement of the poetic papers is fairly logical for locating the manuscripts for a particular poem; for the scholar attempting to bypass Birney's corrupt versions and study authorial texts, however, the arrangement is chaotic. Far more serious than the organization is the fact that the integrity of the poetic archive has been violated. While collecting and arranging Lowry's poetic manuscripts and typescripts, Earle Birney and Mrs. Margerie Lowry, to facilitate filing, cut apart sheets on which Lowry had composed more than one poem, thereby destroying valuable evidence for the cluster-dating of related poems. Also, by disbinding four of Lowry's manuscript notebooks, Birney made it virtually impossible to restore Lowry's compositional sequence, a loss that affects not only dating, but also critical analysis. In addition, Birney scribbled - often, inexplicably, in ink - on many of Lowry's manuscripts and typescripts. Fortunately, Birney's hand is markedly different from Lowry's, so that his substantive emendations are easily distinguishable. However, it is very difficult to determine whether handwritten marks of punctuation are authorial. This problem is especially irritating with regard to cuts indicated by lines or slashes. Equally irksome is Birney's inclusion in many individual files of his own unmarked typescript versions of the poems. Their presence makes it necessary to examine Birney's correspondence in order to generate a chart to identify the papers he typically used in order to distinguish them 

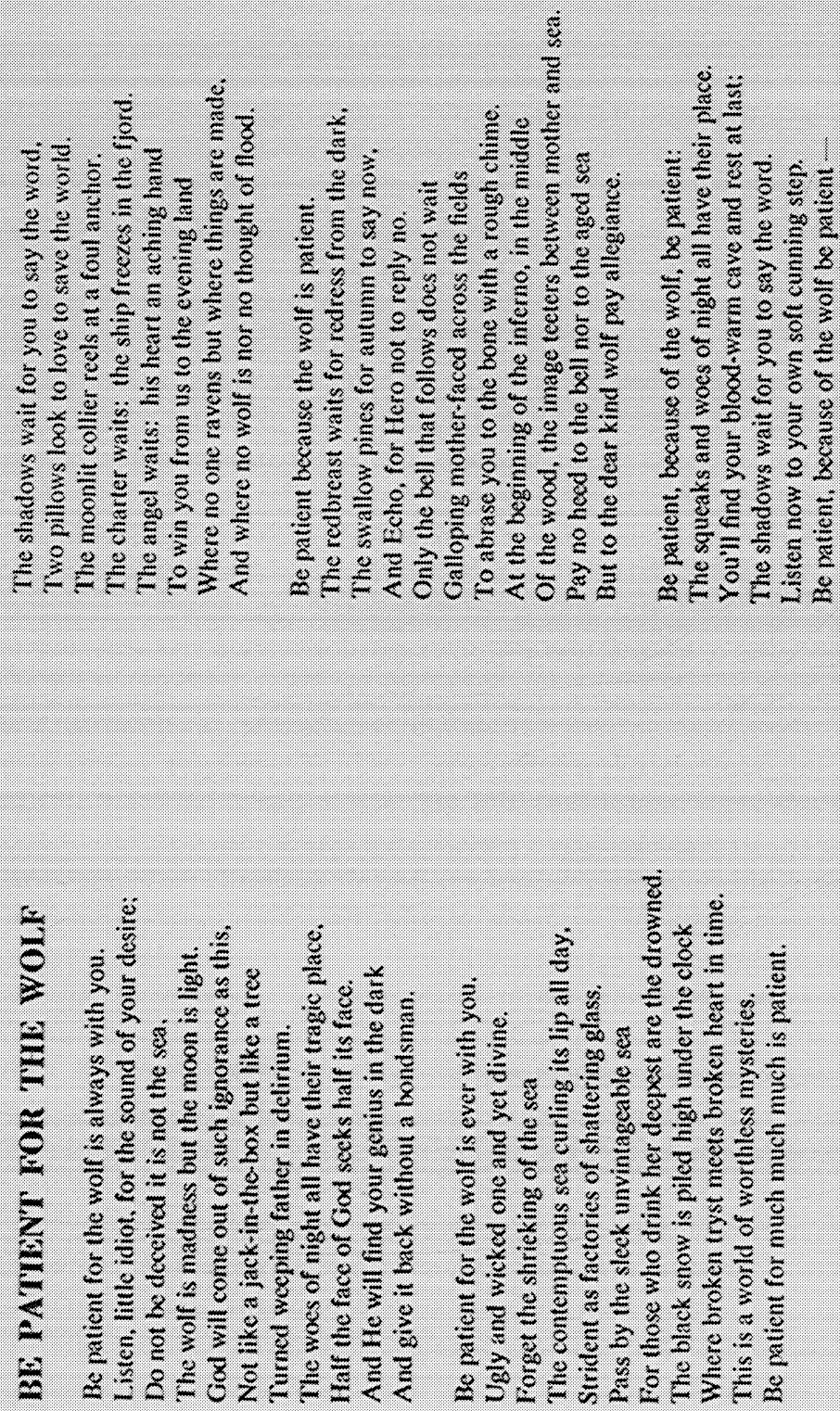

Malcolm Lowry, 'Be Patient For the Wolf,' from Selected Poems of Malcolm Lowry (San Francisco: City Lights Books, I962), pp. 54-5. Copyright (c) 1962 by Marjorie Lowry. Reprinted by permission of City Lights Books. 
from Lowry's and to preclude, or lessen, the risk of bestowing textual authority on Birney's unauthorized revisions.

Lowry's own method of composition and the state of his poetic papers complicate further the chaotic nature of the collection. The fact that he tended to compose on any paper at hand, whether a restaurant menu or the verso of a sheet from a discarded draft of prose, complicates the task of compiling a chronological master-list of Lowry's poems. That these manuscripts can appear anywhere in the entire collection vitiates the value of the poetic inventory. Because Lowry also tended to compose poems in the margins of his prose manuscripts, the compilation of a complete listing of his poems necessitates consulting these manuscripts. For example, the three poems included in the story 'Through the Panama,' published in Hear US O Lord from Heaven Thy Dwelling Place, must be traced back through the multiple drafts of that story; these drafts do not appear in the poetic inventory. The poems in 'Through the Panama' are, as published texts, fairly visible; less easy to discover, however, are unpublished poems jotted in the margin of a draft of a published prose work.

Lowry's eclectic methods of composing and revising his poetry create a bewildering array of manuscripts and typescripts in which little apparent pattern of consistent compositional practice is evident. Confronted only with the poetic collection, one would be tempted to describe Lowry's poetic career as a chaotic mess. Some poems exist in ten to fifteen drafts, some in only one. Some poems are incomplete - the sonnet rhyme scheme, for example, may be jotted beside a poem in which designated lines are missing - and yet still exist in multiple drafts. The chronological line of development for certain poems can seem deceptively simple if one naively assumes that a Lowry manuscript always precedes a typescript.

There is also the rather delicate question of Margerie Lowry's role in the composition process. Mrs. Lowry was responsible for transcribing on the typewriter Lowry's holograph drafts; he would then check the typescripts, sometimes making further revisions. A close collation reveals occasional substantive variants between a holograph draft and a typed version. In these instances, the question of textual priority must be resolved. Should one assume that the Lowrys discussed these variants, thereby conferring authorial status on them? Or, following Fredson Bowers' treatment of Hawthorne's text, simply view the wifely variants as non-authorial and disregard their textual relevance $?^{7}$ Or should one acknowledge that the variants are likely non-authorial, but still grant their authority on the assumption that Lowry himself welcomed, perhaps even needed, Margerie's literary input? Despite the possibility of Mrs. Lowry's editing, the final typescripts should be assigned authority on the grounds that Lowry saw them when checking the typescripts, and, unless further holograph 
revisions were made on these sheets, as they sometimes were, that he approved them. Nowhere on the typescripts did Lowry note that a change from the holograph disturbed him.

Dating the manuscripts is also problematic. Lowry, with few exceptions, did not date his poems, and even if he had, the dates would have to be confirmed through textual analysis. The only reliable way to date the poems is to date the papers - well over Ioo - on which they appear. In order to do so, it is necessary to compile a chart of Lowry's datable outgoing correspondence, and to check the paper types and letter dates in the chart against paper manufacturers' catalogues. It is then possible to date poetry sheets in relation to the correspondence / paper-use chart.

Unfortunately, paper-dating is not always perfectly reliable. The extant holograph draft of 'Xocxitepec,' for example, is pencilled on the verso of a typescript draft of the first page of Mrs. Lowry's thriller The Shapes That Creep, which commences with the unforgettable line, 'They could see at once that the man was very dead.' This novel was published in I946; a letter to Harold Matson from Margerie Lowry suggests that the novel was accepted in $1945 .{ }^{8}$ However, Lowry's biographer Douglas Day states that the novel was begun in 1940 and accepted in I94r. ${ }^{9}$ Either way, paper-dating through the connection to Mrs. Lowry's novel places the poem in the early to mid-I940's, during the first Dollarton, British Columbia period. However, in his letter about the poem's inclusion in the Penguin Book of Canadian Verse, Lowry informed the editor, Ralph Gustafson, that he composed the poem in the margin of the missing first draft of Under the Volcano as he was writing what was to become page 88 , which places the poem in the Mexican period, despite the results of paper-dating.

These are just a few of the problems and questions raised by Lowry's poetic manuscripts, to which no single, global solution is possible. How is it possible, then, to arrive at the latest determinable authorial versions of the poems, and to determine for each poem a complete record of the authorial substantive variants in every version preceding the final copytext? How is it possible, in other words, to attain an accurate and organized version of Lowry's career as a poet, so that we may have something reliable to which we can devote critical attention?

The pursuit of this vision, which has guided my preparation of a scholarly edition of The Collected Poetry of Malcolm Lowry, ${ }^{10}$ demands a fivestep plan: location, transcription, dating, arrangement, and collation. The most significant result of the first stage of work is the addition of some 183 poems to Lowry's known poetic canon: the U.B.C. inventory includes only 296 titles against the 479 extant poems. Following the identification, verification, and transcription of each poem, the next step is to make a thorough paper analysis to determine a terminus a quo and ad quem for all 
manuscript and typescript variants of each title. Once the dates of each poem are definitely, or at least satisfactorily, established, the poems must be grouped according to their compositional periods to convey some idea of Lowry's artistic development as a poet. His poetry presents interesting problems partly because the manuscripts for each compositional period are distinct and diverse. Most challenging, however, are the periods which produced Lowry's two discrete and unpublished collections, The Lighthouse Invites the Storm and the 1947 selection, the integrity of which Birney has ignored. His decision to do so has further complicated an already complex situation, because it obfuscates a clear view of the fixed vision by which Lowry determinedly structured his poetic volumes. In the forthcoming Collected Poetry, the integrity of both volumes is preserved.

The Lighthouse Invites the Storm is Lowry's first collection of poems. It is not clear when Lowry conceived a group of linked poems or a possible sonnet sequence, but he first mentioned the volume in a 1938 letter to Nordahl Grieg. ${ }^{11}$ However, the recurring characters on whom the unified structure of the collection rests - Peter Gaunt and Vigil Forget - are first introduced on draft leaves datable between I934 and I936. Most of the poems were completed by I938-39, when Lowry appears to have had a professional typist in Los Angeles prepare, on 'Grimes Business Bond' paper, a triplicate fair copy of the Lighthouse manuscript. In I939, many of the poems underwent a further round of revisions and were retyped at Lowry's Vancouver apartment on paper which Lowry also used for outgoing correspondence in that year. ${ }^{12}$

That some version of the Lighthouse text - perhaps the originals of the I938-39 fair copy triplicate - was circulating through New York publishing houses in I940-4I is clear from Lowry's correspondence: in I94I he wrote to his agent Harold Matson to ask whether Matson was still holding 'the hapless and ambulatory' Lighthouse. ${ }^{13}$ Although he occasionally toyed with it during the last fifteen years of his life, Lowry left the Lighthouse essentially intact after I940 with the exception of those poems from it which he included in his novel Dark as the Grave, to be discussed presently. It seems clear that he intended the Lighthouse to be a discrete collection: after I940, only eleven of the eighty-three Lighthouse poems at U.B.C. bear traces of further revisions; of these eleven, only three were included with Lowry's second poetry collection in I947. These two facts undermine Birney's view, now widely held, that Lowry intended to work all his poetry into the Lighthouse structure.

No final fair copy of the Lighthouse has surfaced. Lowry's draft copy of the volume, which includes some duplicate poems, some extensive authorial revisions and comments, and some indications of in-process editing and re-ordering, is preserved at the University of British Columbia. 
Unfortunately, this draft copy is reliable only for establishing copy-texts of individual poems, because its authorial structure has been reorganized by Earle Birney. The draft copy contains seven types of paper ranging in dates from 1934 to I940; the draft files for eleven poems contain later papers which can be dated through their appearance in the correspondence. The latest traceable work Lowry did on the Lighthouse is the final version of 'Letter from Oaxaca to North Africa I936,' which appears on paper which dates from I957, the year of Lowry's death. Most of the Lighthouse papers are typescripts; manuscripts survive at U.B.C. for only fourteen of the eighty-three poems.

Given the tempestuous and unsettled nature of the two years of Lowry's life between his flight from Mexico and the beginning of the relatively calm Dollarton period, it seems likely that the missing Lighthouse manuscripts were included with, and suffered the same fate as, the missing Mexican first draft of the Volcano. Therefore, the extant Lighthouse manuscripts are the only surviving papers from the Mexican period, a fact which increases their textual value.

That the variants drop sharply between versions after I938 suggests that the draft of the Lighthouse is one in which the texts were established to Lowry's satisfaction, but in which the order had not been finally determined. For example, several of the poems have Lowry's 'out' scrawled across the top of the typescripts. This data could indicate that a fair copy would have included fewer than the eighty-three poems originally designated for the Lighthouse. However, tracing Lowry's revisions reveals that he did not always revise or title the latest draft of any given poem, using instead whichever version was handy to him at the time. He could easily have changed his mind about the 'out' poems, thus explaining their inclusion in the draft copy. Alternatively, the 'out' poems may have been replaced in the draft by Margerie Lowry and Earle Birney.

It is evident, however, that Lowry revised the order of the Lighthouse poems at least three times: three separate numbering systems appear on most of the typescripts. These roman numerals, which comprise separate series for each of the seven authorial sections, are for the most part handwritten at the top of the sheets, including the Grimes fair copies; the numerals are inscribed in pencil and / or black ink, Lowry's characteristic method of making revisions to typescripts. The I939 Vancouver paper, however, has typed numerals which, along with certain revisions, indicate that the versions for the eight poems which appear on this paper post-date the Grimes versions. There is, however, a list in Margerie's hand of one version of the Lighthouse order which, though nearly consistent with the foliation, does not always agree with any one set of holograph numeration. ${ }^{14}$ Alterations in foliation do not, however, seriously affect the order of 
the collection, for the inconsistencies produce gaps which serve only to collapse the order, rather than change it. These gaps do raise the interesting question of the missing (or perhaps unwritten) poems, especially since no other poems in the U.B.C. collection are numbered in a similar fashion. The order should be determined by the foliation, but the existence of three sets of foliation generates some unresolvable problems, which are most prudently treated thus: wherever there is a single numeral, it serves as order-determinant; in the case of the multiple numerals, the order established by the pages marked with single numerals provides a guide to selecting an appropriate choice of position from among the multiple numerals. Although obviously not definitive, this list likely represents the order in which Margerie found the draft copy of Lighthouse, since it is certainly not a list of the expanded Lighthouse format created by her and her co-editor, nor does it match the current disordered state of the draft copy. Because Lowry himself had not before his death determined a final order for Lighthouse, or because no such order has surfaced, and because it is impossible to know how he would have wanted the work completed, any critical study of Lighthouse should be based on a re-creation of the latest order Lowry had established by the time of his death.

A version of The Lighthouse Invites the Storm makes one other interesting appearance in Lowry's manuscripts. A short selection of Lighthouse poems closes the typescripts for Dark as the Grave; this selection does not appear in the posthumously-published novel. The selection is attributed to Sigbjorn Wilderness, the novel's protagonist and Lowry's alter ego. Because the selection is a discrete segment of another text, it should receive no authority in the Lighthouse stemma.

After a tempestuous flight from Mexico via Los Angeles and Vancouver, Lowry settled into his shack on the beach at Dollarton, British Columbia, where, except for some long visits and journeys, he remained for fourteen years in what was clearly the calmest period of his life. In Dollarton, Lowry achieved a literary maturity he did not possess in Mexico; more and more of his autobiographical poems address the problems of writing. In 'Joseph Conrad,' Lowry expresses his frustration with the rigours of poetic form:

This wrestling, as of seamen with a storm Which flies to leeward - while they, united In that chaos, turn, each on his nighted Bunk to dream of chaos again, or home The poet himself, struggling, with the form Of his coiled work, knows ... 15

The frequency of poems about writing and writers increases in the third 
section of the 1947 selection. In 'Foul, Or Twenty-Five,' Lowry employs a rugby conceit to express the poet's struggle:

Gloom is this weary scrimmage

Of my thoughts to heel some image

Out to where the scrum half-dancing

Of my will to write entrancing

Poems waits to fling the fated

Thing, that will arrive deflated

On the tryline of abortion. ${ }^{16}$

In another Dollarton poem, 'Bright as the Pleiades Upon the Soul,' a storm motif depicts his difficulty with poetic craft:

Wrestling with iambics in the stormy wood

I lost the joy that wind itself may bring:

And yet the wood must struggle with the form of the gale

As poets should with words from that quarter

Of the plains of sense

Bent by its fury

The gale is

The wood composed in peace once more the poem. ${ }^{17}$

Sometime in I946 Lowry decided to assemble from his Dollarton poems a second volume of poetry. On 22 June 1946 he wrote to Albert Erskine:

I've got masses of poems left ... enough to make two volumes I'd thought of calling The Lighthouse Invites the Storm and Wild Bleeding Hearts. ${ }^{18}$

One year later, on 24 June I947, Lowry again mentioned the poems to Erskine; by this point Margerie had 'some fifty' typed out, but they required 'more weeding' before Lowry could send him the poems. Wild Bleeding Hearts is probably the I947 typescript preserved at U.B.C. Lowry possessed the paper used for the poetry typescript by the time of his June I947 letter to Erskine; it appears in correspondence from Dollarton through April and May of 1947. Lowry sent the fifty-four poems, less than one quarter of his Dollarton output, accompanied by a covering letter, to Erskine on 7 November I947; therefore, the tentatively titled Wild Bleeding Hearts must have been assembled sometime between July I946 and November 1947.

Although Lowry included only three of the poems from the Lighthouse, 
he arranged the I 947 selection to reflect his major stages of literary composition up to that point, as the section headings indicate: 'Poems of the Sea,' 'Poems from Mexico,' and 'Poems from Vancouver,' the latter of which comprises the bulk of the volume. Except for the three revised Lighthouse poems, no material in this volume was written before I939-40.

There are manuscripts and multiple drafts for poems in the $1947 \mathrm{selec}-$ tion. The earliest manuscript drafts appear on 7 -by-9 $1 / 4$-inch notebook paper. During the initial organization of the U.B.C. collection, Earle Birney disbound the notebooks in order to create individual files for the poems, but Lowry used at least four, and possibly more, distinct notebooks during I940: blank newsprint, blue-lined pink-margined newsprint, blue-lined unmargined newsprint, and blue-lined pink-margined white paper. At least two of the notebook papers are datable to I940, ${ }^{19}$ and stemmatically close holograph drafts for some individual poems, including 'Stoker Tom's Ukulele' and 'Joseph Conrad,' appear on several of the papers, indicating the tight chronological proximity of the notebooks and the poems in them. A network of drafts criss-crosses the notebook sheets. For example, the six holograph drafts of 'Freighter I940' include drafts for 'A Quarrel,' 'I Met a Man Who Had Got Drunk With Christ,' and 'My Hate Is As a Wind That Buffets Me.' This evidence strongly suggests that Lowry used the notebooks simultaneously.

In I94 I the occurrence of the notebook paper drops sharply in favour of the cheap yellow $81 / 2$-by-II-inch newsprint paper most characteristic of the first (I940-47) Dollarton period. It is also present among the manuscripts for the I94I draft of the Volcano. Intermediate drafts for many poems are datable from their appearance on clearly watermarked white bond papers which also appear in Lowry's outgoing letters between I 942 and I946. The I947 annotated original copy of the 1947 selection, which Lowry sent to Albert Erskine in November of that year, is preserved at U.B.C. in box seven, file two. ${ }^{20}$

Most of the poems in this selection were further revised into the 1950 . Retypings for thirteen poems appear on 'Victory Bond' 81/2-by-II-inch paper, datable to I95 I. Between 1952 and I954 Lowry revised forty-six of the fifty-four poems in this selection, as well as nineteen additional Dollarton poems. This retyping appears on 8-by-Io-inch cream-coloured 'Voucher Bond' paper inscribed with an elite type. This set of sheets is particularly interesting because Lowry evaluated with a letter grade most of the poems included in this retyping. It is quite likely, perhaps even probable, that Lowry intended this final major retyping of his poems to be a revised version of the I 947 selection. The 'Voucher Bond' originals are housed in The McFarlin Library at the University of Tulsa. According to 
Sidney F. Huttner, Curator of Special Collections at the McFarlin Library,

... this group of poems was acquired in early December 1976 at a Sotheby's (London) auction with J. Howard Woolmer acting as our agent. ${ }^{21}$

That sale, located with the assistance of C.F. Forbes, the Colbeck librarian in the Special Collections Division of the U.B.C. Library, was held at Sotheby's Chancery Lane, on I6 and 17 December 1976. The typescript formed part of Lot 6 12, and came from the literary estate of Lowry's friend, English writer and critic John Davenport (I9I0-I963). Included in this lot was a typescript of sixty-eight poems divided by separate title-pages into 'Sea Poems,' 'Mexican Poems,' 'Canadian Poems,' and 'Miscellaneous. ${ }^{22}$ The lot also contained some other items of Lowryana, including letters from Margerie Lowry to John Davenport dated between I96I and I963. The list of prices realized indicates that the entire lot was purchased by 'Stanton' for £rioo. 'Stanton' may have subdivided and sold his lot, because the McFarlin has only their sixty-five typescript poems without title-pages or letters. Margerie Lowry sent the 'Voucher Bond' typescript to John Davenport, hoping he would be able to place them with a British publisher. ${ }^{23}$ Although Margerie and Birney retyped Lowry's poems in the early I960s, the 'Voucher Bond' paper certainly has a rightful place in the stemma, since Lowry's hand appears on several of the 'Voucher' sheets. The fact that these poems appear on one brand of paper, with only one typeface, probably from the same typewriter, and are divided by title-pages which bear a striking similarity to those in Lowry's 1947 selection, strongly suggests that the 'Voucher Bond' sheets represent a third authorial collection, one which is a later and revised version of the I 947 selection, a theory further supported by the fact that forty-six of the fifty-four poems included in the 1947 selection were revised on 'Voucher Bond' sheets.

Problems of stemma are rare in this selection: paper-dating is easily carried out using the correspondence of this period, and the later typescripts are readily identifiable through revisions as well as paper-dating. There is no numeration apparent in the selection: it lacks a table of contents, and the poems are unnumbered and the pages unfoliated, so that no grid exists for determining the authorial order of the selection. However, the original typescript at U.B.C. appears pristine enough to provide the only justifiable basis for ordering the poems, especially since no other basis exists.

Although the I 34 poems which comprise Lowry's two unpublished volumes of poetry represent less than one quarter of his poetic canon, their existence and textual complexity and integrity attest to Lowry's personal emphasis on his poetry. The evidence yielded by archival research, coupled with a necessary dash of informed conjecture, provide the means by which 
Lowry's two authorially-constructed volumes of poetry may finally be unearthed, and added to his canon.

\section{NOTES}

The research for this article stems from the preparation for my scholarly edition of The Collected Poetry of Malcolm Lowry, forthcoming from The University of British Columbia Press. All quotations from the Lowry manuscripts are reprinted with the permission of the Estate of Malcolm Lowry.

I This and the two following quotations are from Selected Letters of Malcolm Lowry, eds. Harvey Breit and Margerie Bonner Lowry (Philadelphia: Lippincott, 1965), pp. 13-14, 59, 408.

2 Malcolm Lowry Papers, Special Collections Division, University of British Columbia Library, box 22, file 23.

3 Sheryl Salloum, Malcolm Lowry: Vancouver Days (Madeira Park, B.C.: Harbour Publishing, I987), p. 69.

4 Malcolm Lowry Papers, box 7, file 2.

5 Ibid, box 22, file 23, lines 3-5.

6 Birney adds 'Thunder Beyond Popocatepetl,' 'Venus,' 'Songs from the Beach: Eridanus,' and 'The Language of Man's Woe'; he omits 'Songs for Second Childhood' and 'The Moon in Scandinavia.'

7 In his introduction to the Centre for the Editing of American Author's Centenary Edition of The Marble Faun (Columbus: Ohio State University Press, I968), Fredson Bowers provided a textual history of Sophia Hawthorne's manuscript emendations, as well as his rationale for excising all traces of her work from her husband's text. This introduction sparked a controversy in the American scholarly community, and caused Edmund Wilson to write his famous attack on the Centre for the Editing of American Authors, 'The Fruits of the MLA,' originally published in The New York Review of Books (26 September and Io October 1968).

8 Malcolm Lowry Papers, box 2, file 2.

9 Douglas Day, Malcolm Lowry: A Biography (New York: Oxford Univ. Press, I973), p. 286.

Io Forthcoming from the University of British Columbia Press, Fall I 99 I.

I I Selected Letters, pp. I5-I6.

I2 A second paper, which contains 'Eight Poems from The Lighthouse Invites the Storm' (box 6, file 55) also dates from this time. This selection accompanied a May I940 letter to James Stern asking him to place the poems. Stern was unsuccessful in this endeavour. The eight poems are: 'In the Oaxaca Train,, 'Delirium in Vera Cruz,' 'Quartermaster at the Wheel,' 'The Devil Was a Gentleman,' 'Doctor Usquebaugh,' 'There is a Metallurgy,' 'The Roar of the Sea and the Darkness,' and 'Lull.'

I3 Malcolm Lowry Papers, box r, file 80.

I4 Ibid, box 6, file 52 . 
I 5 Ibid, box 7, file 2, lines I-6.

I6 Ibid, box 7 , file 2 , lines I-7.

I7 Ibid, box 4, file 65 .

I 8 Selected Letters, p. I 44.

I9 The white blue-lined pink-margined paper appears in outgoing correspondence for I940 (Malcolm Lowry Papers, box I, file 79); in a handwritten note Margerie dates the newsprint blank paper 1940 (ibid, box 2 I, file 8). One type of notebook paper also appears in correspondence for 1945 (ibid, box 2, file 2).

20 There must have been a duplicate typescript, because carbons of the 1947 retyping, on identical paper, exist for five of the fifty-four poems. These poems are: 'Jokes in the Galley,' 'Outward Bound,' 'Mr. Lowry's Good Friday Under a Real Cactus,' 'Death of an Oaxaquenian,' and 'Nocturne.'

2 I Sidney F. Huttner to Kathleen Scherf, 6 October 1987.

22 The Sotheby's cataloguer probably did not realize that three of the unfoliated sheets were not separate poems, but rather second pages of long poems, and thus advertised the group as comprising sixty-eight, instead of sixty-five, poems.

23 Earle Birney Papers, Thomas Fisher Rare Book Library, University of Toronto, box 64 . 